\author{
Krzysztof Janas \\ ORCID: 0000-0001-6765-7275 \\ Uniwersytet Warszawski
}

\title{
Fuck context, czyli splatając architekturę ze społeczeństwem
}

\begin{abstract}
Abstrakt: Publikacje naukowe traktujące o architekturze w zdecydowanej większości skupiają się na analizowaniu relacji między budynkami i ich estetyką z jednej strony a społeczeństwem lub kulturą z drugiej. Obiekty i ich projekty, architekci i ich praca mogą być w tej perspektywie zrozumiałe, dopiero gdy zatrzymamy płynący czas oraz umieścimy je w różnego rodzaju ramach — kontekście, strukturach czy warunkach. Znieruchomiała architektura jest wówczas tu oto i odbija społeczne zjawiska, podczas gdy jej wyjaśnienia są gdzieś tam. Budynki są tu statyczne, trwają sparaliżowane w ustabilizowanej formie o określonym stylu, a jakiekolwiek działania i zdarzenia pozostają na zewnątrz, ukryte i schowane. Jedyne, co pozostaje, to odkrycie tego, co niewidoczne. W artykule proponuję inną optykę. Zależy mi, by pokazać, jak architektura może stawać się poznawalna, a nie interpretowalna, opisywalna, a nie dedukowalna, dynamiczna, a nie statyczna. $Z$ tego względu w swoim wywodzie będę się posługiwać metodą proponowaną przez badaczy z nurtu teorii aktora-sieci. Wychodząc od Koolhasowskiego fuck context, postaram się przeformułować główny cel badania architektury, w którym mniej istotne będzie to, co budynki znaczą, co sobą manifestują i jak generują społeczne postawy, bardziej zaś to, co faktycznie robią. Gdy będziemy się starać zrozumieć, a nie wyjaśniać budynki, śledząc i badając wszelkich aktorów zaangażowanych w dynamiczną sieć składającą się na konkretny obiekt, może się okazać, że na kontekst zabraknie już miejsca, przestanie być nam potrzebny.
\end{abstract}

Słowa-klucze: teoria aktora-sieci, architektura, Rem Koolhaas, kontekst

\section{Wprowadzenie}

W jednej ze swoich książek Kurt Vonnegut przypomina, że w latach sześćdziesiątych w Stanach Zjednoczonych słowo fuck uchodziło za nieprzyzwoite i nie używano go w druku. Drugim równie niebezpiecznym wyrażeniem był komunizm, który w ustach porządnego amerykańskiego obywatela mógł być wypowiadany wyłącznie z nienawiścią i/lub strachem. Władza nad językiem miała być swego rodzaju kluczem do utrzymania stabilności w rozchwianym społeczeństwie, które z coraz większym zdumieniem przyglądało się wyrachowanemu politycznemu szaleństwu wojny w Wietnamie. Swój sprzeciw wobec tej niedorzeczności wkrótce wyraził satyryk Paul Krassner, publikując wymowny plakat 
głoszący — o zgrozo! — „fuck communism!”, wykorzystując przy tym symbolikę flagi amerykańskiej i ruchów komunistycznych ${ }^{1}$.

Jaki związek mogą mieć satyryczny plakat, słowo „komunizm” i troska o purytanizm słownika amerykańskich obywateli z refleksją nad relacją architektury i społeczeństwa? Na pozór żadnego. Tym bardziej że od publikacji Krassnera minęło przecież przeszło pół wieku, społeczeństwa zachodnie mają za sobą rewolucję kulturalną i obyczajową, ruchy emancypacyjne, zimną wojnę czy rozwój mediów społecznościowych. Siejąca wówczas zgorszenie rozwiązłość językowa dziś należy właściwie do codzienności. W późnonowoczesnych warunkach fuck stale gości zarówno na salonach, jak i na koszulkach, a komunizm rozmywa się nawet w Chinach czy na Kubie. Jeśli więc można ,pieprzyć” właściwie wszystko, a zbiór słów zakazanych świeci pustkami, to skąd taki popłoch w polu architektury w rozumieniu Pierre'a Bourdieu ${ }^{2}$ po osławionym już fuck context? ${ }^{3}$ Czyżby wypowiadający te słowa Rem Koolhaas przeprowadził frontalny zamach na święte prawa projektowania, naruszając tym samym pewien porządek w rozchwianym społeczeństwie, które z coraz większym zdumieniem przygląda się otaczającym je budynkom oraz planistyce miast i wsi? Czy — jak twierdzą niektórzy — Koolhaas rujnuje w ten sposób „klasycznie pojmowane definicje piękna, przyczyniając się do wzrostu znaczenia bezguścia i brzydoty"? ${ }^{4}$ A czy Krassner był makkartystą...?

Przyjrzyjmy się Koolhaasowskiemu wyrażeniu ponownie, bez uciekania się do łatwych porównań, a tym bardziej bez wieszczenia apokaliptycznych scenariuszy. Zamiast oburzać się na — bądź co bądź udaną — prowokację, spróbujmy przemyśleć ją na nowo, nie traktując jej jako źródła zgorszenia, lecz niepewności i wątpliwości. W rezultacie może okazać się, że zmieniając perspektywę i oczyszczając pole refleksji ze zbędnych uprzedzeń, pewników i ram, z ustabilizowanego dotychczas świata niewiele pozostanie. Fuck context nie będzie już potrzebne. Po co bowiem ,pieprzyć” coś, czego w gruncie rzeczy nie ma?

${ }^{1}$ K. Vonnegut, Trzęsienie czasu, przeł. M. Słysz, Łódź 2012, s. 220.

${ }^{2}$ P. Bourdieu, L.J.D. Wacquant, Zaproszenie do socjologii refleksyjnej, przeł. A. Sawisz, Warszawa 2001.

${ }^{3}$ Stwierdzenie to szybko obrosło środowiskową legendą i stało się łatką przyklejaną Koolhaasowi i innym architektom, którzy w swoich projektach stawiają na większą autonomię twórczą, ucieczkę od utartych schematów i projektowych kalek oraz odrzucają założenia architektury modernistycznej. Często zapomina się jednak, że owo fuck context w mniejszym stopniu stanowiło manifest Koolhaasa, bardziej zaś było elementem (wyrwanym — nomen omen — z kontekstu) jego diagnozy świata architektury. Dla lepszego jej zrozumienia warto więc przywołać pełną wypowiedź holenderskiego architekta: „Wzięte łącznie wszystkie te zerwania — ze skalą, z kompozycją architektoniczną, z tradycją, z przejrzystością, z etyką — prowadzą do ostatecznego, najbardziej radykalnego zerwania: architektura Bigness nie jest już częścią tkanki miejskiej. Bigness istnieje w niej, co najwyżej współistnieje. A w podtekście mówi: pieprzyć kontekst" - R. Koolhaas, Bigness, czyli o problemie Wielkości, [w:] idem, Śmieciowa przestrzeń, przeł. M. Wawrzyńczak, Warszawa 2017, s. 50.

${ }^{4}$ T. Markowski, A. Kowalewski, P. Śleszyński, Studia nad chaosem przestrzennym. Synteza. Uwarunkowania, skutki i propozycje naprawy chaosu przestrzennego, Warszawa 2018, s. 92. 


\section{Tu architektura, tam społeczeństwo}

Zacznijmy jednak od próby określenia, na czym polega specyfika naszego myślenia o architekturze, naszej postawy poznawczej wyrażającej się w projektowaniu, krytyce i badaniach. Wydaje się, że dla współczesnej architektury charakterystyczne jest towarzyszące jej od początków nowoczesności permanentne rozdarcie - między sztuką a rzemiosłem, między inżynierią a projektowaniem, między bezwzględnymi prawami nauk ścisłych a pluralizmem humanistyki. Dialektyka ta idzie jednak znacznie dalej. W duchu nowoczesnym (odnoszącym się tu do znacznie szerszego zjawiska niż nurt architektury modernistycznej) architektura musi się bowiem mierzyć nie tylko z odmiennymi sposobami jej uprawiania, lecz wręcz z zupełnie osobnymi rzeczywistościami, w których musi funkcjonować i które musi łączyć. Chodzi tu o przeciwstawiane sobie - zarówno poznawczo, jak i praktycznie naturę i kulturę, obiekty i ludzi, architekturę jako materialną formę i społeczeństwo, któremu ta forma ma służyć. Zgodnie z witruwiańską tradycją poszukiwanie źródeł, badanie obecnych i projektowanie nowych form architektonicznych ma więc umożliwić poszukiwanie źródeł, badanie obecnych i projektowanie nowych form społecznych, których architektura jest zawsze swego rodzaju odbiciem ${ }^{5}$. Jednocześnie, utrzymując założenie dotyczące oddzielności tych światów, dokonujemy także ruchu w przeciwnym kierunku i staramy się wytłumaczyć architekturę społecznym lub kulturowym zewnętrzem - warunkami, bazą, ramą czy kontekstem.

Fundamentalne dla obydwu tych podejść jest tym samym założenie, że by zrozumieć architekturę - proces projektowania, sukcesy i porażki projektów oraz samych obiektów czy też móc rzucić nieco światła na przestrzenną organizację miast lub wyjaśnić, dlaczego dany styl pojawia się i rozprzestrzenia w konkretnym momencie historycznym — konieczne jest umieszczenie jej w pewnych ogólnych, stałych i jasno zdefiniowanych ramach. Kartezjańskie oddzielenie poznającego od świata zewnętrznego i oczyszczenie tegoż świata z niuansów skazuje tym samym obiekty architektoniczne na bezczynne trwanie. Mamy ,jakiś” budynek (posłużmy się tu dla przykładu fabryką) powstały w wyniku ,pewnych warunków społecznych” (dziewiętnastowieczny kapitalizm), stojący „gdzieś tam” (miasto przemysłowe) i czekający na zinterpretowanie go przez ekspertów przy użyciu „ram teoretycznych” (kapitalistyczna produkcja i reprodukcja stosunków i materii społecznej). W gruncie rzeczy nie wiemy wiele więcej niż wcześniej, a architektura i społeczeństwo nadal nieruchomo stoją w przeciwnych narożnikach.

Chociaż architektura, przestrzeń i cała sfera materialności w ostatnich latach stają się ponownie przedmiotem dyskursu publicznego, to zwrot ten ufundowany jest $\mathrm{w}$ znacznej mierze na tych właśnie zastanych schematach myślowych, utrzymujących lustrzany podział na architekturę i społeczeństwo, a innymi słowy

${ }^{5} \mathrm{~S}$. Kent, A cross-cultural study of segmentation, architecture and the use of space, [w:] Domestic Architecture and the Use of Space: An Interdisciplinary Cross-Cultural Study, red. S. Kent, Cambridge 1990, s. 129. 
— na formę i funkcję. Jeszcze innymi — na to, co należy do kulturowego świata znaków, i to, co pozostaje w martwej sferze materialności, na ludzi, dyskursy i obiekty czy wreszcie - na typowe dla nowoczesności rozróżnienie podmiotu i przedmiotu. Nie mając środków narracyjnych mogących połączyć świat materii ze światem społecznym, nadal zamykamy więc budynki w przestrzeni euklidesowej $^{6}$, w której nieruchomieją i stają się martwym elementem scenografii dla społeczeństwa i jego (umiarkowanej) dynamiki. Ich projekty, opisy czy wyjaśnienia i reprezentacje muszą nie tylko odnosić się do ,społecznego kontekstu ich czasu", wręcz konieczne jest ugruntowywanie ich w nim, dodając im w ten sposób solidności, trwałości i spójności. Lepiej zrozumiemy więc budynki, gdy tylko dodamy do nich „społeczny wymiar” czy „,społeczne warunki”, będziemy w stanie wyjaśnić proces projektowania czy style projektowe, jeśli weźmiemy pod uwagę „pewne społeczne czynniki i wpływy”, a historię obiektów architektonicznych, gdy umieścimy ją w linearnej historii społeczeństwa ${ }^{7}$. W tej perspektywie „to, co społeczne" staje się zatem obiektywizującą ramą, która pozostaje gdzieś na zewnątrz, determinując jednocześnie „to, co materialne” i to do tego stopnia, że nie da się pomyśleć o budynku bez uwzględnienia tego, co przed, wokół, obok czy ponad - zarówno w sensie przestrzennym, jak i czasowym. A już na pewno nie da się go bez tego zaprojektować. Co w takich warunkach może mieć na celu Koolhaasowskie fuck context? Czy istotnie jest perwersyjnym odwróceniem się „od tego, co społeczne” i ucieczką w sferę niepohamowanej niczym swobody, w której królują „,bezguście i brzydota”? A może jednak jest zupełnie odwrotnie i Koolhaas stara się przekroczyć zarysowaną tu chorobę dwubiegunową, która w nowoczesności trapi architekturę, oraz proponuje nam środki rozkurczowe uruchamiające nasze myślenie nie przez pryzmat tego, w jakich ramach mieszczą się obiekty, lecz w poprzek obecnych podziałów i skupiając się na tym, czym i po co właściwie jest architektura oraz jak działa?

\section{To, co społeczne, po nowemu}

Aby zrozumieć tę strategię, spróbujmy posłużyć się metodą proponowaną przez badaczy z nurtu teorii aktora-sieci (action-network theory — ANT). Już w tym miejscu niezbędne jest jednak pewne zastrzeżenie — przekroczenie dualizmów oraz odrzucenie ram teoretycznych nie może przecież udać się za pomocą kolejnej teorii, jedną ramę zamienilibyśmy jedynie na inną. ANT — pomimo nie-

${ }^{6}$ B. Latour, A. Yaneva, "Give me a gun and I will make all buildings move": An ANT's view of architecture, [w:] Explorations in Architecture: Teaching, Design, Research, red. R. Geiser, Basel 2008.

${ }^{7}$ A. Yaneva, Made by the Office for Metropolitan Architecture: An Ethnography of Design, Rotterdam 2009, s. 18-22. 
fortunnej nazwy - nie jest jednak teorią, lecz metodą badawczą ufundowaną na empirycznych studiach przypadku i wyłącznie z tej perspektywy możliwe jest jej zrozumienie i aplikowanie ${ }^{8}$.

Upraszając, należy wskazać, że teoria aktora-sieci wywodzi się ze studiów nad nauką i technologią (science and technology studies - STS) oraz z metod badawczych nazywanych etnografią bądź antropologią laboratorium, które od połowy lat siedemdziesiątych ubiegłego wieku starają się rzucić wyzwanie tak zwanym dualizującym sposobom mówienia i uprawiania nauki ${ }^{9}$. Zamiast stosować zastane (i statyczne) modele wiedzy rozdzielające to, co wyjaśniane, od tego, co wyjaśnia, oraz poszukujące przyczyn i skutków, przedstawiciele ANT śledzą procesy i praktyki, translacje i mediacje prowadzące do wytwarzania lub destabilizowania się powiązań pomiędzy aktorami, którymi mogą być zarówno podmioty ludzkie, jak i nie-ludzkie, przedmioty materialne oraz niematerialne. To w tych zróżnicowanych powiązaniach — w duchu teorii aktora-sieci — konstytuuje się ,to, co społeczne", które nie jest żadną osobną dziedziną rzeczywistości, lecz konkretną sytuacją, do tego niezwykle złożoną i dynamiczną ${ }^{10}$. W optyce ANT — jak utrzymuje Bruno Latour, najważniejszy z jej przedstawicieli — podział rzeczywistości na dwie (trzy, cztery czy sto cztery) oddzielne sfery jest bezużyteczną fikcją i to wcale nie dlatego, że są one z sobą nierozerwalnie splecione i takie puryfikujące cięcie jest niemożliwe, ale dlatego, że w gruncie rzeczy nie ma żadnych osobnych sfer, które można i należałoby oddzielać ${ }^{11}$.

Dlaczego taka zmiana perspektywy miałaby być aż tak znacząca? Otóż, utrzymując podział na dwie osobne rzeczywistości, pomiędzy którymi co rusz musimy przerzucać most, w istocie tylko komplikujemy, a nie - jak mogłoby się wydawać - oczyszczamy świat ze wzajemnej krzątaniny natury, kultury, ludzi, zwierząt, obiektów, idei, sądów czy emocji. Tak naprawdę jedynie tworzymy w ten sposób niezliczone hybrydy, w ramach których poznawani przez nas ludzie, byty oraz zdarzenia zawsze i tak pozostają niepoznawalne w pełni, ponieważ nie jest możliwe jednoznaczne określenie, ani do jakiego „świata” należą, ani jak się mają do innych bytów czy działających na nie „sił”. Wykonujemy więc iście Cortazarowski ruch — szukamy społeczeństwa nie tam, gdzie ono jest. A jeśli już udaje nam się je odnaleźć, to nie potrafimy dostrzec w nim „tego, co społeczne”. A jeśli nawet to dostrzegamy, nie potrafimy tego zrozumieć, a może nie chcemy, a może tylko udajemy, że tego szukaliśmy. A może — jak proponuje Latour -

8 J. Law, Actor-network theory and material semiotics, [w:] The New Blackwell Companion to Social Theory, red. B.S. Turner, Oxford 2018, s. 141-158.

${ }^{9}$ K. Abriszewski, Ł. Afeltowicz, Jak gotym okiem zobaczyć rosnace neurony i site alergii? Krążaca referencja w nauce i poza nia, „Zagadnienia Naukoznawstwa” 2007, nr 3-4, s. 406.

${ }^{10}$ A. Yaneva, Actor-network-theory approach to archaeology of contemporary architecture, [w:] Oxford Handbook of the Archaeology of the Contemporary World, red. P. Graves-Brown, R. Harrison, A. Piccini, Oxford 2013, s. 7-8.

11 Zob. m.in. B. Latour, Nigdy nie byliśmy nowocześni, przeł. M. Gdula, Warszawa 2011. 
w ogóle nie ma społeczeństwa? ${ }^{12}$ Co więc pozostaje? Systemy oraz stale wymykające się nam ich interferencje, modele idealnotypiczne, agregaty i relacje władzy. Znów nie wiemy wiele więcej niż wcześniej. Znów musimy coś do nich dodać. Znów ustawiamy się w kolejce po stypendia i granty. Wydaje się, że tę nowoczesną pułapkę dostrzega również Koolhaas i przeczuwa, że koniec końców w myśleniu architektonicznym (w myśleniu tout court) nie da się wyjść poza, gdyż w gruncie rzeczy nie ma żadnego poza. Ani wobec projektowania, ani wobec rzeczywistości. A skoro nie ma, szkoda czasu na zastanawianie się nad tym, w jaki sposób wskoczyliśmy tu, gdzie jesteśmy. Hic Rhodus, hic salta? Fuck context!

Jeśli jednak odrzucimy dualizujący sposób myślenia, to co właściwie otrzymamy w zamian? Okazuje się, że podążając w mrówczej (ant) pracy za aktorami, główna zagadka, jaką dotychczas należałoby rozwiązać (,,istnienie szczególnych społecznych więzi ujawniających ukrytą obecność jakichś specyficznych sił społecznych"13), staje się wówczas... samym rozwiązaniem. Rose is a rose is rose is a rose. Możemy teraz interpretować rzeczy jako takie, jakimi są, a nie skupiać się na ciągłym poszukiwaniu magicznych mocy, które z pewnością oddziałują na te rzeczy. Dostrzegamy nagle i z niemałym zdumieniem, że

nie ma nic specyficznego w porządku społecznym; że nie istnieje wymiar społeczny żadnego rodzaju ani „kontekst społeczny”, ani jakaś osobna dziedzina rzeczywistości, którą można by opatrzyć etykietą „,społeczny” czy „społeczeństwo”; że nie są dostępne „siły społeczne”, dzięki którym „wyjaśniono by” pozostałe właściwości, których nie są w stanie opisać inne dziedziny; [...] że „społeczeństwo” zupełnie nie będąc kontekstem, „w którym” wszystko się dzieje jak w ramie, powinno zostać potraktowane jako ruch elementów krążących w obrębie maleńkich kanalików ${ }^{14}$.

Odwrócenie okazuje się tu zatem dosyć radykalne. To, co dotychczas wyjaśniało się pod postacią kontekstu, wymiaru czy czynników, teraz samo wymaga wyjaśnienia. „To, co społeczne” przestało być enigmagicznym klejem, który stabilizuje porozdzielane obszary rzeczywistości, a stało się tym, co posklejane z różnorodnych i aktywnych aktorów - ludzkich, nie-ludzkich, materialnych i niematerialnych. Świat znów drży, znów jest działaniem i dynamicznie zmieniającą się rzeczywistością, w której porządek ustępuje zmianie, i jest coraz trudniejszy do ujęcia, jest jedynie migotliwym wyjątkiem od reguły.

\section{Poruszyć nieruchome}

Czy w tym drżącym i niestabilnym świecie jest jeszcze miejsce na badanie architektury manifestującej przecież stabilność i trwałość? Tak i nie. Ignorowanie tego, co

12 B. Latour, Splatajac na nowo to, co społeczne. Wprowadzenie do teorii aktora-sieci, przeł. A. Derra, K. Abriszewski, Kraków 2010, s. 346.

13 Ibidem, s. 10.

${ }^{14}$ Ibidem. 
jest, pozostawiałoby nas zdezorientowanymi wobec otaczających nas bytów i zdarzeń co najmniej w takim stopniu, jak zdezorientowani są obserwatorzy niemogący nadziwić się himalaistom, że po raz kolejny podejmują ryzykowne próby zdobycia szczytu. „Najgłębszy” sens badania budynków w „płaskiej” rzeczywistości, w której wszystkie byty są jakościowo równe i nie ma żadnego zewnętrza, jak rozumie to Latour, jest więc właśnie taki jak sens zdobywania Czomolungmy. Ponieważ istnieje. Możemy też do tego dodać istotne badawczo stwierdzenie, że „w zabudowie nawarstwia się miniony czas, odkłada się historia społeczności wkomponowana w jej codzienność" 15 , co z kolei prowadzi nas do konieczności badania w optyce temporalnej nie tylko „tego, co materialne”, lecz nawet powiązań pomiędzy architekturą i codziennością miejsca oraz zbiorowości, w której funkcjonuje. Dodanie czwartego wymiaru do architektury, czyli właśnie czasu, niewiele jednak zmienia, od kiedy znamy koncepcję czasoprzestrzeni, czasu jako przedłużenia przestrzeni i związanego z tym ruchu. W dalszym ciągu nasze lenistwo i pokusa chodzenia na skróty może skierować nas ku stabilnym i martwym w swej stabilności obiektom, które w wyniku „zmieniających się w czasie warunków zewnętrznych” same w końcu także będą ulegały przekształceniom. Strona bierna nadal trzyma się mocno. Odwrotnie niż w fotografii, która stara się zatrzymać to, co w ruchu, czwarty wymiar w architekturze może być pomocny, dopiero gdy służy nam do tego, by poruszyć to, co wydaje się nieruchome. Właśnie dlatego ANT sugeruje myślenie o budynkach jako o aktywnych oraz dynamicznie działających aktorach, których sprawczość jesteśmy w stanie obserwować poprzez śledzenie powiązań i przekształceń dokonywanych przez nich w relacji do innych aktorów ${ }^{16}$. Jak stwierdzają Bruno Latour i Albena Yaneva w Give me a gun and I will make all buildings move, tekście fundującym niejako podejście do badań nad architekturą w duchu teorii aktora-sieci:

Każdy wie — a w szczególności właśnie architekci — że budynek jest nie statycznym obiektem, lecz pozostającym w ruchu projektem; że nawet jeśli został już wybudowany, to starzeje się, jest przekształcany przez swoich użytkowników, modyfikowany przez wszystko to, co dzieje się wewnątrz i na zewnątrz; oraz że przeminie albo zostanie odnowiony, przekształcony i zmieniony nie do poznania ${ }^{17}$.

Badania nad budynkami z perspektywy ANT są więc rewolucyjnie nierewolucyjne. Nie skupiamy się na tym, do czego może być zdolna architektura w odniesieniu do takich ,zewnętrznych wobec niej wymiarów”, jak historia, siły ekonomiczne i polityczne, relacje i praktyki społeczne, władza, klasa, płeć czy rasa — jak w podejściach poststrukturalnych. Nie skupiamy się też na tym, jak wymiary te reprezentowane są przez architekturę ani na odkrywaniu głęboko ukrytych znaczeń, które chowały się dotychczas za martwą i trywialną sferą oczywi-

15 Zob. M. Łukasiuk, Lokalność w kontekście architektury i atmosfery, „Societas/Communitas” 2015, nr 1-2, s. 225-235.

${ }^{16}$ K. Fallan, Architecture in action: Traveling with actor-network theory in the land of architectural research, ,Architectural Theory Review” 13, 2008, nr 2.

${ }^{17}$ B. Latour, A. Yaneva, op. cit., s. 80. 
stości ${ }^{18}$. Nie musimy zatem rozwikływać już zagadek z dziedziny symboli. Nie potrzebujemy szklanej kuli, w której „to, co społeczne” wyjaśniałoby nam losy badanego obiektu. Rozwiązujemy umowę na świadczenie kulturowych horoskopów i zwracamy się ku codzienności, ku przyziemnym sprawom. Pokazujemy w zamian, jak obiekty mogą stawać się poznawalne, odkrywamy i opisujemy sposoby istnienia i ścierania się różnorodnych aktorów zmobilizowanych w sieci relacji oraz śledzimy i rozpoznajemy wielorakie powiązania, które są efektem tych starć $^{19}$. Mniej interesuje nas to, co obiekty znaczą, bardziej zaś to, co faktycznie robią.

W tym ujęciu nie może tym samym istnieć budynek statyczny, tkwiący w bezruchu. Obiekty, które nie działają - zarówno te wybudowane, pozostające nadal na papierze, jak i wyburzone, lecz tkwiące w pamięci - tracą swoje powiązania $\mathrm{z}$ innymi aktorami (bogatą właścicielką, zaangażowanym konserwatorem, skrupulatną historyczką sztuki, biernym użytkownikiem, nieinteresującą nikogo ideą, bankrutującym miastem, osuwającym się terenem, technologią prefabrykacji czy znowelizowaną ustawą) i stopniowo muszą zanikać - nie tylko w sensie fizycznym, ale i niematerialnym. W krótkich słowach — budynki, które nie działają, umierają. W jeszcze krótszych — bezruch to zbrodnia. Architekturę, która sprawia wrażenie niezmienności, która manifestuje swoją stabilność, można by więc określić raczej jako swego rodzaju latouriańską ,,czarną skrzynkę” — obiekt działający w sposób nieproblematyczny, oczywistość w życiu codziennym, co do której nie ma potrzeby zastanawiać się, jak właściwie funkcjonuje ${ }^{20}$. Budynki doświadczane przez nas jako stabilne i nieruchome są zatem w tym ujęciu w ciągłym ruchu, który polega na gromadzeniu, mobilizowaniu, ścieraniu i łączeniu heterogenicznych bytów ludzkich i nie-ludzkich w sieci relacji, w której obiekty wyłaniają się, rozwijają i przekształcają. Projektanci i pręty, obrotowe drzwi i bezdomni, drewniane stropy i nielegalnie zatrudnieni budowlańcy, gęstość betonu i naczelny architekt miasta, chropowatość ścian i gniazdo szerszeni, ruchome schody i Ludwig Mies van der Rohe - każdy z tych aktorów jest tu dla nas potencjalnie równie istotny, ponieważ może być w danej relacji tak samo konkretny oraz może mieć swoje bardzo konkretne konsekwencje.

Tego rodzaju myślenie prowadzi nas zatem do zwrócenia się ku bogatym a pomijanym często właściwościom architektury, ku całej jej złożoności wykraczającej daleko poza badania nad funkcją i formą. Ku temu, co tworzy, dzieje się i umiera na naszych oczach. Ku sprawczości budynków i zdarzeń oraz procesów, jakie wywołują. Ku zmiennej w czasie kompozycji ich różnorodnych materiałów i tekstury, ich zapachów, dźwięków, gry światła i cieni. Ku temu, jak są użytkowane i przekształcane, jak swoją przestrzenną organizacją umożliwiają wyko-

${ }_{18}$ Zob. A. Yaneva, Made by the Office..., s. 18-22.

19 A. Yaneva, Actor-network-theory approach ..., s. 22-23.

${ }^{20}$ Zob. m.in. K. Abriszewski, Poznanie, zbiorowość, polityka. Analiza teorii aktora-sieci Bruno Latoura, Kraków 2012. 
nywanie jednych czynności, podczas gdy ograniczają wykonywanie innych. Ku sformalizowanym dyskusjom na biennale i nieformalnym opiniom w internecie. Otwiera nas to na wszystkie te sytuacje, w których to, co subiektywne, i to, co obiektywne, przestaje być przeciwstawne i stabilne, a staje się wielorakie, posplatane i zmienne, w których sieć angażująca i wiążąca byty pozbawiona jest hierarchii, a każde nowe rozdanie, każda rekonfiguracja aktorów i zdarzeń znów jest ontologicznie możliwa ${ }^{21}$. Z punktu widzenia ANT architektura, przy całej swojej stałości wynikającej z „domknięcia czarnej skrzynki” — skutecznej translacji, harmonijnemu dostrojeniu aktorów i uzyskaniu jedności - może być więc jednocześnie traktowana na wskroś dynamicznie, jako „zbiory przekształceń i sieci interakcji aktorów wpływających na rzeczywistą, wyobrażoną, wyobrażaną czy projektowaną tkankę architektoniczną"22.

\section{W poszukiwaniu metody}

Teoretyczne rozważania pozostają jednak wyłącznie teoretycznymi i mało kogo interesującymi rozważaniami tak długo, jak — również w duchu ANT - nie zostaną powiązane $\mathrm{z}$ empirycznymi studiami przypadku lub nie znajdą sojuszników. W związku z tym, że zasadniczym celem rozważań w tym miejscu nie jest to pierwsze, pozostaje zadowolenie tych czytelników, którzy - zaintrygowani próbą rewizji Koolhaasowskiego wyrażenia - dotrwali do obecnego punktu. Kto jednak liczył na idealny przepis, złoty klucz do badania architektury z perspektywy teorii aktora-sieci i rozwiązanie dzięki temu wszystkich architektonicznych zagadek, ten... się przeliczy. ANT w swoim założeniu odrzuca przecież właśnie taki sposób poznawania rzeczywistości — łatwy, uproszczony i z góry zakładający, jaka ta rzeczywistość jest, a więc de facto przesądzający o rezultatach samego poznania. Stosowanie ANT do analiz i badań wymaga zatem nie tylko poznawczej ciekawości, lecz przede wszystkim gotowości na zmiany i nagłe zwroty akcji, choćby miały one być nie po naszej myśli oraz negowały wszelkie pierwotne hipotezy. Co więcej, w zależności od punktu wyjścia, z jakiego zaczniemy badania ,po ANT-owsku”, od skali i zakresu, jaki przyjmiemy w naszych obserwacjach, od tego, jak długo będą one trwały, ilu będziemy mieli w nich sojuszników, jak duży zdobędziemy na nie grant i jak efektywnie będziemy go wykorzystywać, wyniki naszych poszukiwań mogą być z goła odmienne. Dlatego też w wypadku teorii aktora-sieci ,aplikacja czegokolwiek jest tak rzadka jak dobry tekst w naukach społecznych", jak stwierdza

${ }^{21}$ A. Yaneva, Actor-network-theory approach..., s. 21-22.

22 A. Leśniak, Muzeum Sztuki Nowoczesnej w Warszawie. Projekt budynku jako kontrowersja wobec modernizacji i globalizacji, [w:] Historia sztuki wobec globalizacji. Studia z metodologii historii sztuki, red. M. Poprzęcka, Warszawa 2013, s. 114. 
ironicznie Latour ${ }^{23}$. Nie oznacza to jednak, że tak jak ANT porzuca dualistyczne uprawianie nauki, tak i nas zostawia osamotnionych i zdezorientowanych w polu badań. Teoria aktora-sieci jako nie-teoria, lecz metoda daje nam bowiem liczne wskazówki, które — choć nie dają gwarancji powodzenia - mogą być pomocne przy lepszym i bardziej empirycznym zrozumieniu architektury. Przyjrzyjmy się dwóm najbardziej z nich podstawowym.

Po pierwsze, w optyce ANT obiekt architektoniczny nie może stawać się ani bardziej rzeczywisty, ani bardziej zrozumiały, gdy opisze się go przy użyciu specjalistycznego języka lub zanurzy w narracji symbolicznej albo estetycznej, oddzielając go przy tym od innych obiektów, idei, historii danego miejsca i historii jego powstawania. Jest wręcz przeciwnie - obiekt architektoniczny staje się tym bardziej rzeczywisty i tym bardziej zrozumiały, im bardziej powiążemy go ze wszystkim tym, co go otacza, co realnie na niego oddziałuje i na co oddziałuje on sam. Podstawowym zadaniem architektów i badaczy powinno więc być skrupulatne podążanie za budynkami w obserwacjach i analizach, śledzenie ich powiązań oraz laboratoryjny empiryczny opis wszystkich relacji zachodzących w sieci ${ }^{24}$. Im bliżej uda nam się podejść, im więcej aktorów i ich działań będziemy w stanie rozpoznać i zanotować, im więcej specyficzności weźmiemy pod uwagę, tym nasze badanie będzie dokładniejsze. Im bardziej będziemy popadać w generalizację, w szukanie wyjaśnień w ramach i teoriach, które przyłożymy do pozyskanego materiału, zamiast dać temu materiałowi mówić za siebie, tym bardziej będziemy oddalać się od tego, co badane. To sekwencja detali wyznacza całość. Nie ma architektury w ogóle ani budynku w ogóle. Poznanie i zrozumienie obiektów możliwe jest nie przez ściany, drzwi, okna, sąsiedztwo i użytkowników, ale przez sposoby ich istnienia i działania - te konkretne ściany, tamte specyficzne drzwi, te określone okna, tamto wyjątkowe sąsiedztwo i tych szczególnych użytkowników. To oni, one i ich powiązania wyznaczają porządek budynku, który powinniśmy starać się zrozumieć.

Po drugie, powyższe założenie nie powinno prowadzić nas wyłącznie do zwrócenia się ku mikrokonkretom i pojedynczym interakcjom. Odrzucając podział na makro i mikro, zewnętrze i wnętrze, odrzucamy bowiem nie tylko podział, ale i samo makro, mikro, zewnętrze i wnętrze. Żaden aktor nie może być tym samym ani redukowalny, ani nieredukowalny od żadnego innego - ani większego, ani mniejszego ${ }^{25}$. Na tym właśnie polega wspomniana już ,płaska” ontologia. Ponieważ wszystkie byty są jakościowo równe, możemy dowolnie przechodzić od detalu do ogółu, od śrubki w drzwiach do fabryki ją produkującej, od uniwersyteckich zajęć z historii idei do Franka Lloyda Wrighta, od podupadającego dworca

${ }^{23}$ B. Latour, Splatajac..., s. 226.

${ }^{24}$ K. Abriszewski, Ł. Afeltowicz, op. cit., s. 407.

25 Zob. m.in. B. Latour, Pasteurization of France, przeł. A. Sheridan, J. Law, Cambrige, Mas.-London 1993. 
w Wałbrzychu do szczytu G20 w Buenos Aires. I z powrotem. Wymiar makro nie jest już ani bardziej znaczący, ani bardziej wpływowy, przestaje określać

jakiś szerszy czy też większy obszar, wewnątrz którego można osadzić mikro, jak w przypadku rosyjskich matrioszek, a staje się innym, równie lokalnym i w pełni mikromiejscem, które jest podłączone do wielu innych poprzez jakieś medium przenoszące jakiś konkretny typ śladów ${ }^{26}$.

Czy styl szklanej kopuły przebudowanego budynku Reichstagu możemy wyjaśnić otwartością i transparentnością niemieckiej demokracji, a bryłę Casa de Música arogancją Koolhaasa? Znów — tak i nie. Tak, jeśli takie połączenia poprzedzi rzetelna praca teoretyczna i empiryczna, która te konkretne połączenia będzie w stanie wykazać. Nie, jeśli wyjaśnienia te będą się opierać wyłącznie na zaczerpniętych z zewnątrz uproszczeniach. Szklana kopuła Reichstagu mogłaby wówczas równie dobrze być metaforą kruchości (jak kruche jest szkło) odradzającego się po zjednoczeniu państwa niemieckiego lub kruchości samej demokracji, a Casa de Música być „wypadkiem przy pracy” jednego z architektów, który przypadkiem natknął się $\mathrm{w}$ pracowni na zapomniany model jednego $\mathrm{z}$ niezrealizowanych wcześniej projektów i pomyślał: „A gdyby tak...?”. Na marginesie warto dodać, że w wypadku obiektu z Porto to drugie jest akurat bliskie prawdzie, co przekonująco pokazała Yaneva w swoim raporcie z etnograficznych badań w $\mathrm{OMA}^{27}$.

Podejście do architektury w duchu ANT skupia się tym samym na tworzeniu performatywnego, a przy tym pragmatycznego i do gruntu empirycznego wymiaru łączącego budynki z innymi aktorami, praktykami i wydarzeniami, które doprowadziły do jego powstania, ze sposobami ich istnienia, użytkowania i przetwarzania. Śledząc konkretne powiązania różnorodnych aktorów, ich ścieżki i działania, indywidualne aktywności i zbiorowe praktyki, jesteśmy w stanie otworzyć się na nowy, a przy tym zdecydowanie bogatszy repertuar opisów obiektów, praktyk, instytucji i połączeń między nimi. Tworząc tego rodzaju raporty, śledząc niestabilności i zmienności w tym, co wydaje się stabilne i jednorodne w konkretnym miejscu i czasie, będziemy mogli poznać specyfikę obiektów oraz na nowo spleść architekturę ze społeczeństwem ${ }^{28}$. Budynki nie są jedynie projekcjami ani reprezentacjami społeczeństwa, lecz bardziej

prowizoryczną wizualizacją, którą można modyfikować i podług własnej woli unieważniać, powracając do pojedynczych składników, by następnie, odkrywszy jeszcze inne, nowe narzędzia, regrupować owe elementy w nowy zbiór ${ }^{29}$.

${ }^{26}$ B. Latour, Splatajac..., s. 257-258.

${ }^{27}$ A. Yaneva, Made by the Office..., s. 86-90.

${ }^{28}$ A. Yaneva, Actor-network-theory approach..., s. 23.

29 B. Latour, Tarde's Idea of Quantification, cyt. za: L. Manovich, Czym jest wizualizacja?, przeł. M. Korzewski, [w:] Fotospoteczeństwo. Antologia tekstów z socjologii wizualnej, red. M. Bogunia-Borowska, P. Sztompka, Kraków 2012, s. 443. 
Architektura nie jest zatem sama w sobie społeczna, ale może się taka s ta w a ć, ponieważ ma zdolność do gromadzenia i łączenia (assemble) różnorodnych aktorów w heterogenicznych kombinacjach oraz mobilizowania ich do tworzenia nowego. „To, co społeczne” nie jest więc dla architektury żadną zewnętrzną strukturą, która wyjaśniałaby nam proces projektowy, style i losy obiektów. Społeczeństwo nie jest - i nigdy nie było - wystarczającym źródłem rozumienia architektury. Zamiast być odbiciem (więźniem?) kontekstu, budynki jako aktywni aktorzy same funkcjonują jako znaczące (signifier) w sieci relacji i tworzą sojusze, poprzez które wytwarzają własny punkt odniesienia, otoczenie i kontekst. A więc jednak kontekst...?

\section{Czyli co właściwie z tym kontekstem?}

Czy możemy zatem na koniec stwierdzić, że gdzieś na zewnątrz obserwowanego przez nas budynku czyha ostatecznie jakiś kontekst, który pomoże nam wyjaśnić, dlaczego budynek ten pełni tę, a nie inną funkcję lub nie pełni żadnej? Albo jak powinien zostać zaprojektowany? Dlaczego wygląda tak, a nie inaczej? Czemu wzbudza takie, a nie inne dyskusje czy uczucia? Zamiast szukać wyjaśnień w ten sposób, w duchu ANT powinniśmy raczej rozważać kontekst — jeśli już musimy — jako pewną zmienną, jako coś, co ewoluuje, przemieszcza się i przekształca wraz z zaangażowanymi w nim aktorami i praktykami. Raz jest tu, innym razem gdzie indziej. Gdy już zaczynamy się w nim zanurzać, okazuje się, że utknęliśmy na mieliźnie, choć byliśmy pewni, że wypływamy na głębokie wody, a może nigdzie nie wypływaliśmy, tylko taplamy się w brodziku, a może to nie był żaden brodzik, tylko Historia szaleństwa $w$ dobie klasycyzmu Foucaulta, a my tak naprawdę stoimy na przemokniętej deszczem Brackiej w Krakowie albo w jeszcze innym miejscu nie na miejscu. Kontekst, który zawsze nam umyka, jest więc pochodną wielu wymiarów, które zderzają się i nakładają na siebie na każdym etapie procesu projektowego i na każdym etapie życia budynku, tworząc — jak Koolhaasowski Bigness (bo czy Bigness to nie przypadkiem dzisiejszy kontekst...?) — warunki do

swobodnego mnożenia się wydarzeń w jednej bryle. Rozwija strategie organizujące zarówno ich niezależność, jak i współzależność w ramach większej całości, w symbiozie, która nie podważa specyficzności, lecz ją wzmacnia ${ }^{30}$.

Zamiast analizować wpływy zewnętrznych czynników (siły rynkowe, podziały klasowe, ekonomiczne ograniczenia, społeczne konwencje, klimat kulturowy, kampanie marketingowe i polityczne) na „to, co materialne” oraz na procesy jego

${ }^{30}$ R. Koolhaas, op. cit., s. 54. 
wytwarzania, powinniśmy starać się uchwycić migotliwe, zmienne i nieobliczalne zachowania i aktywności różnego rodzaju rzeczy, obiektów, ludzi, instytucji $\mathrm{i}$ technologii ${ }^{31}$.

Czy to właśnie na myśli miał Koolhaas? O to już jego należy zapytać. Patrząc na architekturę z perspektywy ANT, strategia fuck context nie wydaje się jednak ani nihilistycznym odwróceniem się od historii i tradycji, której dotyczy projekt, ani cynicznym zaniechaniem namysłu, analiz, badań i prób poznania rzeczywistości, ani zuchwałym porzuceniem „klasycznie pojmowanych definicji piękna”. To bardziej przemyślana taktyka oparta na głębokim zrozumieniu współczesności i problemów, jakie stawia ona przed architekturą, oraz tego, czym w ogóle architektura jest. Postulując niezależność od kontekstu, Koolhaas nie namawia do tego, by projektować bez jakichkolwiek ograniczeń i „,wymiotować jeszcze większą ilością architektury”32, lecz zachęca do przemyślenia wszystkiego od nowa, za każdym razem, w każdym miejscu. Zobowiązuje nas do myślenia o XXI wieku i architekturze XXI wieku przy pomocy zupełnie innych paradygmatów i narzędzi niż te, w których poruszamy się przez ostatnie dziesięciolecia, oraz do „zmierzenia się z zasadniczą kwestią zmiany skali, która wydaje się konieczna właśnie dlatego, że nie możemy już niczego uznać za zewnętrzne"33. Jak na to mógłby zareagować Paul Krassner?

\section{Fuck context, or interweaving architecture with society}

\section{Abstract}

The majority of architectural studies tends to focus on relationships between architecture and its materiality on the one hand and the society or culture, on the other. In this perspective, buildings and projects, architects and their work can be understood only by placing them within the social context, structures, frames and conditions. Architecture is here and mirrors societal changes and processes, while the explanations are there. Buildings are stable, there is no action, all moves and all flows are outside, behind or hidden and the only thing researchers and designers should do is to unveil them. The ambition of this article is different. Starting from Rem Koolhaas's well-known phrase — "fuck context" - I argue that the main purpose of studying architecture should not be explaining or interpreting buildings but trying to understand them and to follow, account and examine all (human and non-human) actors involved in the dynamic architectural network. This is why I propose to apply the Action-Network Theory as a new method of studying and analyzing architecture in the humanities and social sciences but also in architecture theory. If we pay attention to details, to actors and their actions as much as it is possible, to their associations and connections, to what buildings $d o$ rather than what they mean, a new and richer version of architecture will appear. And there will be no place, no necessity for context.

Keywords: ANT, Action-Network Theory, architecture, Rem Koolhaas, context, fuck context

31 A. Yaneva, Actor-network-theory approach..., s. 24-25.

${ }^{32}$ R. Koolhaas, op. cit., s. 53.

${ }^{33}$ B. Latour, Ostukując architekturę Koolhaasa laseczką ślepca, przeł. A. Leśniak, „Architektura Murator" 2007, nr 1, s. 44. 


\section{Bibliografia}

Abriszewski K., Poznanie, zbiorowość, polityka. Analiza teorii aktora-sieci Bruno Latoura, Kraków 2012.

Abriszewski K., Afeltowicz Ł., Jak gołym okiem zobaczyć rosnące neurony i siłę alergii? Krążca referencja w nauce i poza nia, „Zagadnienia Naukoznawstwa” 2007, nr 3-4.

Bourdieu P., Wacquant L.J.D., Zaproszenie do socjologii refleksyjnej, przeł. A. Sawisz, Warszawa 2001.

Fallan K., Architecture in action: Traveling with actor-network theory in the land of architectural research, „Architectural Theory Review” 13, 2008, nr 2.

Kent S., A cross-cultural study of segmentation, architecture and the use of space, [w:] Domestic Architecture and the Use of Space: An Interdisciplinary Cross-Cultural Study, Cambridge University, red. S. Kent, Cambridge 1990.

Koolhaas R., Bigness, czyli o problemie Wielkości, [w:] idem, Śmieciowa przestrzeń, przeł. M. Wawrzyńczak, Warszawa 2017.

Latour B., Nigdy nie byliśmy nowocześni, przeł. M. Gdula, Warszawa 2011.

Latour B., Ostukując architekturę Koolhaasa laseczka ślepca, przeł. A. Leśniak, „Architektura Murator" 2007, $\mathrm{nr} 1$.

Latour B., Pasteurization of France, przeł. A. Sheridan, J. Law, Cambrige, MA-London 1993.

Latour B., Splatając na nowo to, co społeczne. Wprowadzenie do teorii aktora-sieci, przeł. A. Derra, K. Abriszewski, Kraków 2010.

Latour B., Yaneva A., "Give me a gun and I will make all buildings move": An ANT's view of architecture, [w:] Explorations in Architecture: Teaching, Design, Research, red. R. Geiser, Basel 2008.

Law J., Actor-network theory and material semiotics, [w:] The New Blackwell Companion to Social Theory, red. B.S. Turner, Oxford 2018.

Leśniak A., Muzeum Sztuki Nowoczesnej w Warszawie. Projekt budynku jako kontrowersja wobec modernizacji i globalizacji, [w:] Historia sztuki wobec globalizacji. Studia z metodologii historii sztuki, red. M. Poprzęcka, Warszawa 2013.

Łukasiuk M., Lokalność w kontekście architektury i atmosfery, „Societas/Communitas” 2015, nr 1-2.

Manovich L., Czym jest wizualizacja?, przeł. M. Korzewski, [w:] Fotospołeczeństwo. Antologia tekstów z socjologii wizualnej, red. M. Bogunia-Borowska, P. Sztompka, Kraków 2012.

Markowski T., Kowalewski A., Śleszyński P., Studia nad chaosem przestrzennym. Synteza. Uwarunkowania, skutki i propozycje naprawy chaosu przestrzennego, Warszawa 2018.

Vonnegut K., Trzęsienie czasu, przeł. M. Słysz, Łódź 2012.

Yaneva A., Actor-network-theory approach to archaeology of contemporary architecture, [w:] Oxford Handbook of the Archaeology of the Contemporary World, red. P. Graves-Brown, R. Harrison, A. Piccini, Oxford 2013.

Yaneva A., Made by the Office for Metropolitan Architecture: An Ethnography of Design, Rotterdam 2009. 